J. Asiat. Soc. Bangladesh, Sci. 47(1): 23-34, June 2021 DOI: https://doi.org/10.3329/jasbs.v47i1.54184

\title{
BREEDING BIOLOGY OF COMMON KINGFISHER (ALCEDO ATTHIS, LINNAEUS 1758)
}

\author{
HABIBON NAHER ${ }^{1}$, NOOR JAHAN SARKER ${ }^{2}$ AND \\ SHAWKAT IMAM KHAN ${ }^{3}$ \\ ${ }^{I}$ Department of Zoology, Jagannath University, Dhaka-1000, Bangladesh \\ ${ }^{2}$ Department of Zoology, University of Dhaka, Dhaka-1000, Bangladesh \\ ${ }^{3}$ Department of Natural History, Bangladesh National Museum, Shahbag, \\ Dhaka-1000, Bangladesh
}

\begin{abstract}
The breeding biology of the common kingfisher (Alcedo atthis) was studied from 2008 to 2011 in Dhaka North City Corporation and Savar Upazilla. The breeding season was April to September. It laid 3 to 7 glossy white, almost round eggs with a size of $2.5 \pm 0.3$ $\mathrm{cm}$ length, $2.2 \pm 0.3 \mathrm{~cm}$ breadth, and $5.3 \pm 0.7 \mathrm{~g}$ weight. It incubated for 16 to 21 days. During hatching, the hatchlings' weight ranged from 8.5 to $10.5 \mathrm{~g}$ and total body length from 43.2 to $58.6 \mathrm{~mm}$ whereas, it was 30.1 to $32.7 \mathrm{~g}$ and 151 to $155.5 \mathrm{~mm}$, respectively, during fledging. Hatching success was $83.3 \%$. Stolen by people $(13.9 \%)$ and infertility $(2.8 \%)$ were the causes of egg loss. The young birds fledged out after 21 to 27 days of hatching. A total of $56.7 \%$ of nestlings were unable to fly due to stolen $(43.3 \%)$, deaths due to unknown reasons $(6.7 \%)$ and deaths due to natural disaster $(6.7 \%)$. The breeding success was $36.1 \%$ in relation to eggs laid and $43.3 \%$ in relation to eggs hatched.
\end{abstract}

Key words: Egg, Hatchling, Fledgling, Breeding success, Common kingfisher, Alcedo atthis

\section{Introduction}

The common kingfisher, Alcedo atthis (Linnaeus 1758) (order Coraciiformes; Family Alcedinidae), nests in holes in sandy or loamy embankments considering the soil particle composition of nesting banks and some other related factors like compactness, porosity, etc. (Heneberg 2004). It avoids sites with sparse or very dense vegetation, prefers rivers with the availability of fish, about $54-60 \mathrm{~mm}$ shallow waters and of course, demands sandy or loamy banks for nesting (Morgan and Glue 1977, Iribarren and Nevado 1982, Raven 1986, Peris and Rodriguez 1996, 1997, Campos et al. 2000). Thus, habitat is one of the most important factors determining the distribution and settlement of species (Partridge 1981). An appropriate nesting site must offer food, shelter from predators and

*Corresponding author: <likhi.habibon@gmail.com>. 
unfavorable weather conditions ( $\mathrm{Li}$ and Martin 1991, Martin and Roper 1988). Wetland degradation, water pollution, climate change and disturbances caused by fish farmers create threats to them. Although they may get benefit from human dams and fish farming, they are at risk of poisoning through bioaccumulation of pollution and toxins in their fish prey (Rayner et al. 1991). Several studies have been done on ccommon kingfishers globally, (Raven 1986, Reynolds and Hinge 1996, Peris and Rodriguez 1997, Sayako et al. 2002, Heneberg 2004, Kasahara and Katoh 2008) and in Bangladesh (Naher and Sarker 2015, 2016, 2018). However, information on the breeding biology of common kingfishers is restricted in Bangladesh and even in the world. To take conservation initiative of this species, one should know their detailed breeding biology. Hence, the present study investigated the breeding biology of common kingfishers (Alcedo atthis). The objectives of this study were to determine reproductive success, mortality rates and the causes of eggs and fledgling loss. With this knowledge, we will be able to make a conservation plan to sustain the species by protecting nest and nestlings by reducing the challenges.

\section{Materials and Methods}

The fieldwork was performed twice a week during the breeding season, from 7:00 am to 7:00 pm, following focal animal sampling at 5 minutes intervals (Altmann 1974). Pair formation and courtship behavior were noted under several headings: (i) Advertising display: One bird squatting on a tree branch, calling and jerking its head right and left and flying from one branch to another around the other bird, (ii) Head bobbing: Squatting on a tree branch, head jerking up and down while neck and nape drew back and almost or actually touched the back, (iii) Mutual display: While one bird displayed, the other bird joined with and did the same. During this time, both birds sat side by side on the same or different branches ( 0.05 to $2 \mathrm{~m}$, median $=1.5 \mathrm{~m}, \mathrm{n}=42$ ), (iv) Courtship flight: While the pair chased each other by flying up and down in a zig-zag fashion and calling, (v) Mounting: While one bird mount over another with or without cloaca contact.

The eggs were marked as I, II, III and so on with permanent ink and measured with slide calipers and weighed with a spring balance and care was taken to avoid excessive disturbance when first seen. The breeding success was calculated by using the following formulae:

Hatching success $(\%)=($ No. of eggs hatched $/$ total no. of eggs laid $) \times 100$

Fledging success $(\%)=($ No. of nestlings fledged $/$ total no. of nestlings hatched $) \times 100$

Breeding success $(\%)=($ No. of eggs laid $/$ No. of nestlings fledged $) \times 100$ 
Study area: The study was done at Nikunja 1 in Dhaka North City Corporation Area and three villages (Sinduria, Boro-Walia, and Kashipur) under Savar Upazilla. Nikunja-1 $\left(23.82500^{\circ} \mathrm{N} 90.42002^{\circ} \mathrm{E}\right)$ is located on the west side of the Dhaka Airport highway. There are two Lakes, one at the east $(668.5 \times 17.07 \mathrm{~m})$ and another one at the west side $(218.13 \times 75.05 \mathrm{~m})$ of the Nikunja 1 residential area. The northern and southern side of Nikunja 1 is bounded by Nikunja 2 residential area and Dhaka Cantonment Gulf field, respectively. One nest was built at the bank of the eastern lake of Nikunja-1 in 2009, which was reused in 2010. On the other hand, Savar Upazila is located in the Dhaka district and covers 280.13 sq. km. Sinduria $\left(23.88137^{\circ} \mathrm{N}\right.$ and $\left.90.23320^{\circ} \mathrm{E}\right)$, Boro-Walia $\left(23.88627^{\circ} \mathrm{N}\right.$ and $\left.90.25197^{\circ} \mathrm{E}\right)$ and Kashipur $\left(23.88483^{\circ} \mathrm{N}\right.$ and $\left.90.24294^{\circ} \mathrm{E}\right)$ villages were located under Boro-walia Union in Savar Upazila of Dhaka district. One nest was found at Bara Walia, which was reused in 2010 and 2011. One nest was built at Sinduria in 2010 which was reused in 2011. One nest was found at Kashipur in 2011. These villages are located at the Jahangirnagar University Campus.

\section{Results and Discussion}

Breeding season: The breeding season started from April and continued up to September. Most of the observers around the world, including the Indian subcontinent, found that the breeding season covered more or less the same months as found in the present study in Bangladesh (Whistler 1986, Ali and Ripley 1987, Singer 1996). But a quite different finding was observed by Grimmett et al. (1998), who found the breeding season from November to June in India.

Pair formation: Pair formation occurred through a course of displaying behavior. Advertising display was recorded for one to seven days (mean $4.8 \pm 1.2, \mathrm{n}=9$ pairs). The advertiser started its display by squatting on the branch of densely covered trees (Dalbergia sisoo, Albizia procera, or Morus indica) hanging over the water. This behavior was followed by head bobbing which occurred 14 to 49 times per minute (mean $21.9 \pm 4.9, \mathrm{n}=42$ of 3 birds). Ali and Ripley (1983), Anderton and Rassmussen (2005) also reported the advertising display of white-throated kingfishers.

Mutual display: Head bobbing was followed by courtship flight which was recorded for 1 to 3 days (mean $1.8 \pm 1, \mathrm{n}=6$ ), through which the pair formation occurred permanently. After pair formation, one partner offered food to the other, sometimes the other bird received it or not. This behavior is known as 'engagement fish'. Courtship involved chasing each other with calling and usually culminates in the male catching and offering the female an 'engagement fish'. 
Sexual behavior: Mounting took place within 1 to 2 days of pair formation, lasting for 1 to 3 seconds while cloaca contact did not occur, but it increased to 3 to $7 \mathrm{sec}(4.5 \pm 1$, $\mathrm{n}=12$ ) while cloaca contact occurred. During mounting, both partners flapped their wings with calling. After mating, both partners flew away towards the nearby branches and preened their feathers for 1 to 5 minutes (median 4.2, $\mathrm{n}=12$ ).

Nest site selection and territory establishment: After pair formation, both the partners selected abandoned and isolated nest sites, near or away from human habitation (Figs. 12). They chose a vertical, sandy-loam area where they could dig holes comfortably. The pair searched for newly cut down slopes or eroded hills/heaps at the bank of the lake, pond, river, or near the paddy field and ditch (Naher and Sarker 2016).
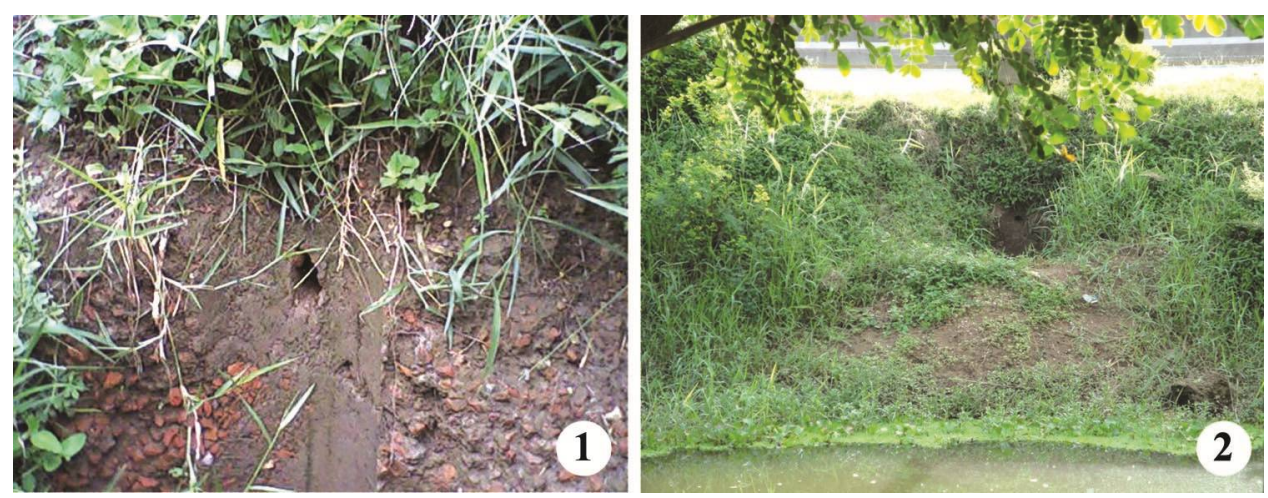

Figs. 1-2: 1. Nest of common kingfisher. 2. Nest of common kingfisher beside a water body.

Nest: The nest was a $36.5 \mathrm{~cm}$ long horizontal tunnel with an oval-shaped entrance, the vertical diameter was $8.25 \mathrm{~cm}$ and the horizontal diameter was $4.25 \mathrm{~cm}$. The widened oval shaped egg chamber with $11.6 \mathrm{~cm} \times 12.7 \mathrm{~cm}$ size was built at the end of the nest. Only one nest was built in the nest site. The same observation was reported by Naher and Sarker (2016).

Clutch size: In May and June, it laid eggs. The clutch size varied from 2 to 7 eggs (mean $4.5 \pm 1.5, \mathrm{n}=8)$. Clutch of 5 was common $(50 \%)$. Clutch sizes of 4 to 8 eggs were reported in different areas of the world (Jerdon 1982, Flegg 1984, Whistler 1986, Ali and Ripley 1987). Various factors are responsible for the variability of clutch sizes such as the condition of the breeding female, availability of resources necessary to produce eggs, time of laying in the season and anticipated future availability of food for feeding nestlings (Klomp 1970, O’Connor 1984, Lessels and Krebs 1989). 
Color and shape of the egg: The color of the egg was glossy white (Fig. 3). It may be pinky white, white or pure unmarked China-white of hard texture with a high gloss (Finn 1978, Jerdon 1982, Flegg 1984, Singer 1996, Whistler 1986, Ali and Ripley 1987).

The egg was almost round (Fig. 3). Flegg (1984) and Jerdon (1982) reported such a shape. Whistler (1986) and Ali and Ripley (1987) described the spherical-shaped eggs.

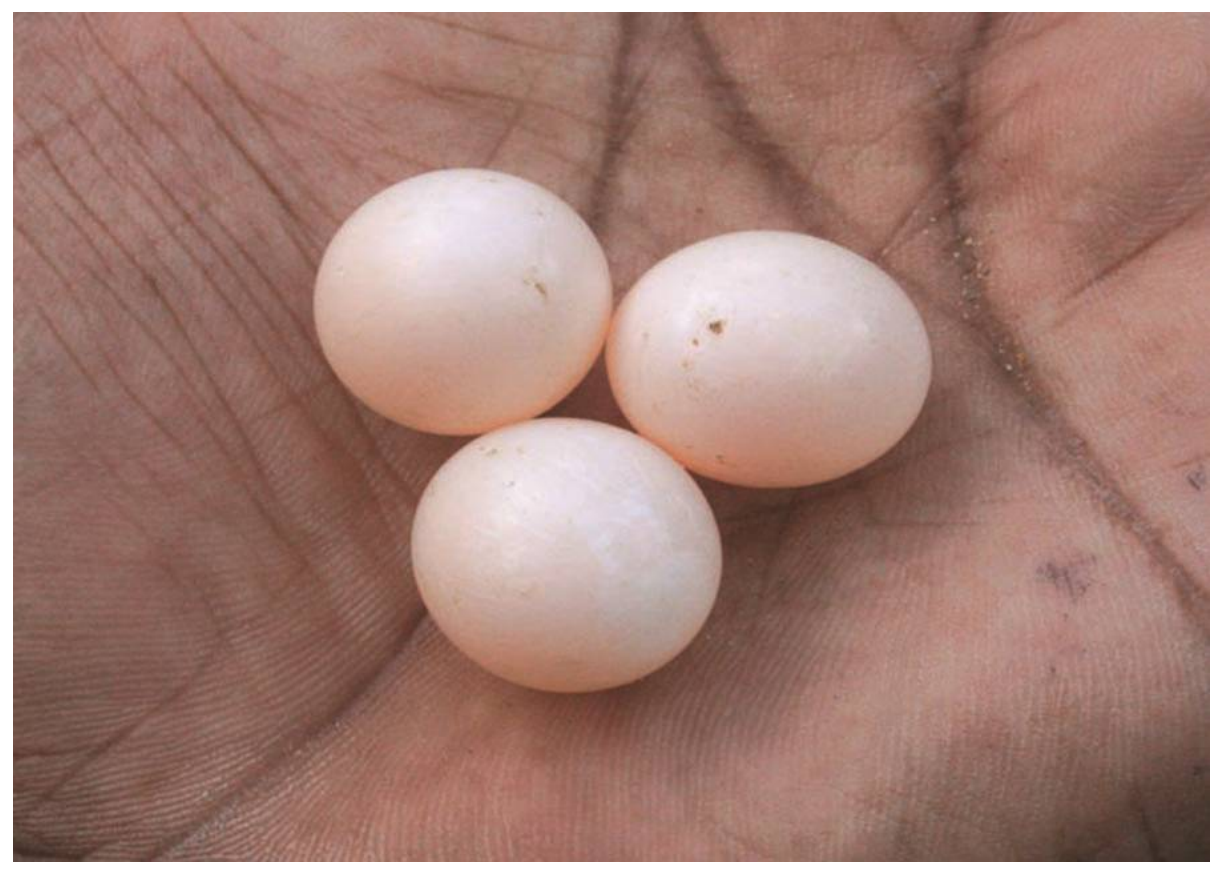

Fig. 3. Eggs of common kingfisher.

Morphometry of eggs: The length, width and weight of the eggs varied from 2.01 to 2.91 $\mathrm{cm}(2.5 \pm 0.3, \mathrm{n}=36), 1.8$ to $2.5 \mathrm{~cm}(2.2 \pm 0.3, \mathrm{n}=36), 4.9$ to $7.5 \mathrm{~g}(5.3 \pm 0.7, \mathrm{n}=36)$, respectively (Table 1$)$. The length is significantly correlated with width $(\mathrm{r}=0.81, \mathrm{df}=34, \mathrm{p}$ $<0.05)$ and weight $(\mathrm{r}=0.55, \mathrm{df}=34, \mathrm{p}<0.05)$, even width is also significantly correlated with weight $(\mathrm{r}=0.38, \mathrm{df}=34, \mathrm{p}<0.05)$.

Incubation period: The incubation period ranged from 16 to 21 days (18.5 days $\pm 1.1, \mathrm{n}$ $=8$ ). Different clutches of different nests had different incubation period and the test was statistically significant $(\mathrm{r}=0.264, \mathrm{df}=6, \mathrm{p}<0.05)$. Almost same observation was made by different workers (Ali and Ripley 1987, Singer 1996). 


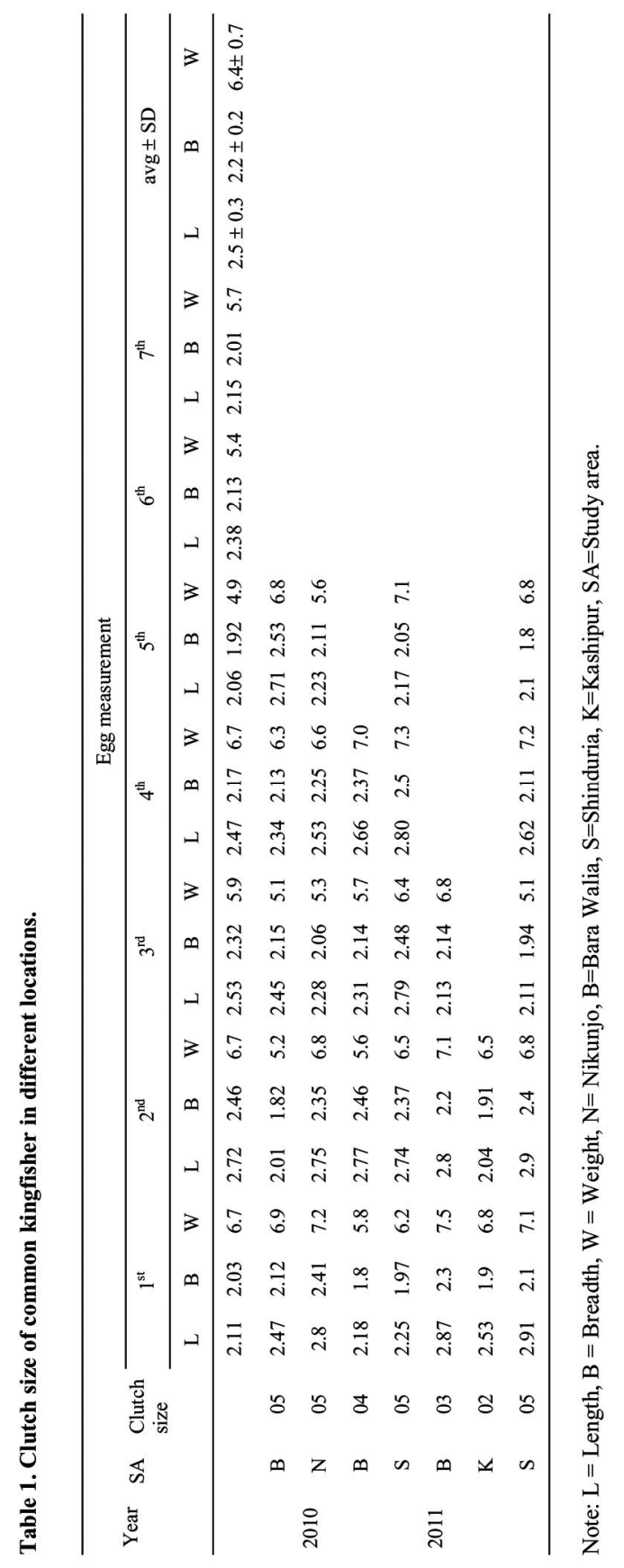


Hatching and hatching success: One $(79.2 \%, \mathrm{n}=24)$ to three $(4.2 \%, \mathrm{n}=24)$ eggs were hatched in one day. As soon as the first egg hatched out, the parents started collecting and providing food to the hatchling alternatively. For example, one partner took $3 \mathrm{~min}$ to 40 $\min (19.5 \pm 12, \mathrm{n}=35)$ to feed the nestlings at a time and repeatedly did the same.

The hatching success was $83.3 \%(\mathrm{n}=36)$. The mean brood per nest was 3 . However, the eggs were lost due to stealing by people (13.9\%) or remained unhatched due to infertility (2.8\%) (Table 2).

Physical feature of the hatchling: The newly hatched hatchling was naked with transparent body skin and flesh colored. The beak and claws were black. Eyes were closed. Eyelids appeared large and dark gray. Egg tooth was present which were disappeared at the $7^{\text {th }}$ to $9^{\text {th }}$ days of hatching. The claw, wing, and tail feathers were absent (Figs. 4 and 5). The measurement of hatchlings and fledglings is represented in Table 3.
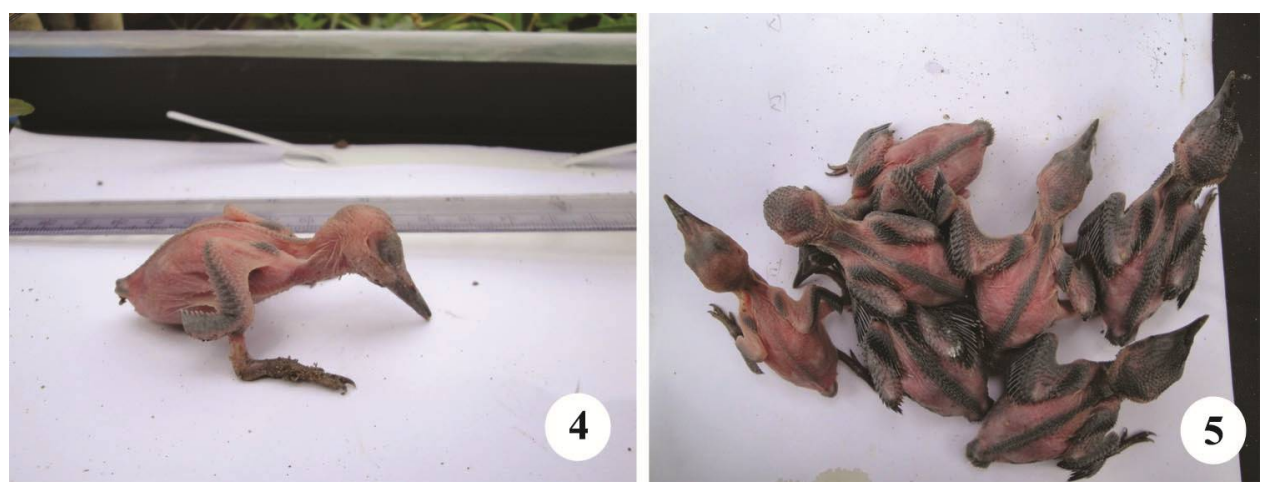

Figs. 4-5: 4. Physical feature of the hatchlings of common kingfisher. 5. Physical feature of the nestlings of common kingfisher.

Opening of the eyes: The eyes started to open after the $7^{\text {th }}$ to $8^{\text {th }}$ days of hatching, which were completely opened at the age of $10^{\text {th }}$ to $12^{\text {th }}$ days. Cramp et al. (1988) recorded pied kingfisher opened its eyes after the $9^{\text {th }}$ day of hatching.

Fledging period: After 20 to 22 days of hatching, the nestlings started to practice flying. They first tried to glide from the nest to nearby branches of the trees, paddy fields, or any support where they could perch easily. The eldest nestlings' seen comparatively took more time (25-27 days) to fledge than others (21-24 days). The average fledging periods ranged from 21 to 27 days ( 24.8 days $\pm 1.1, \mathrm{n}=16$ ). 


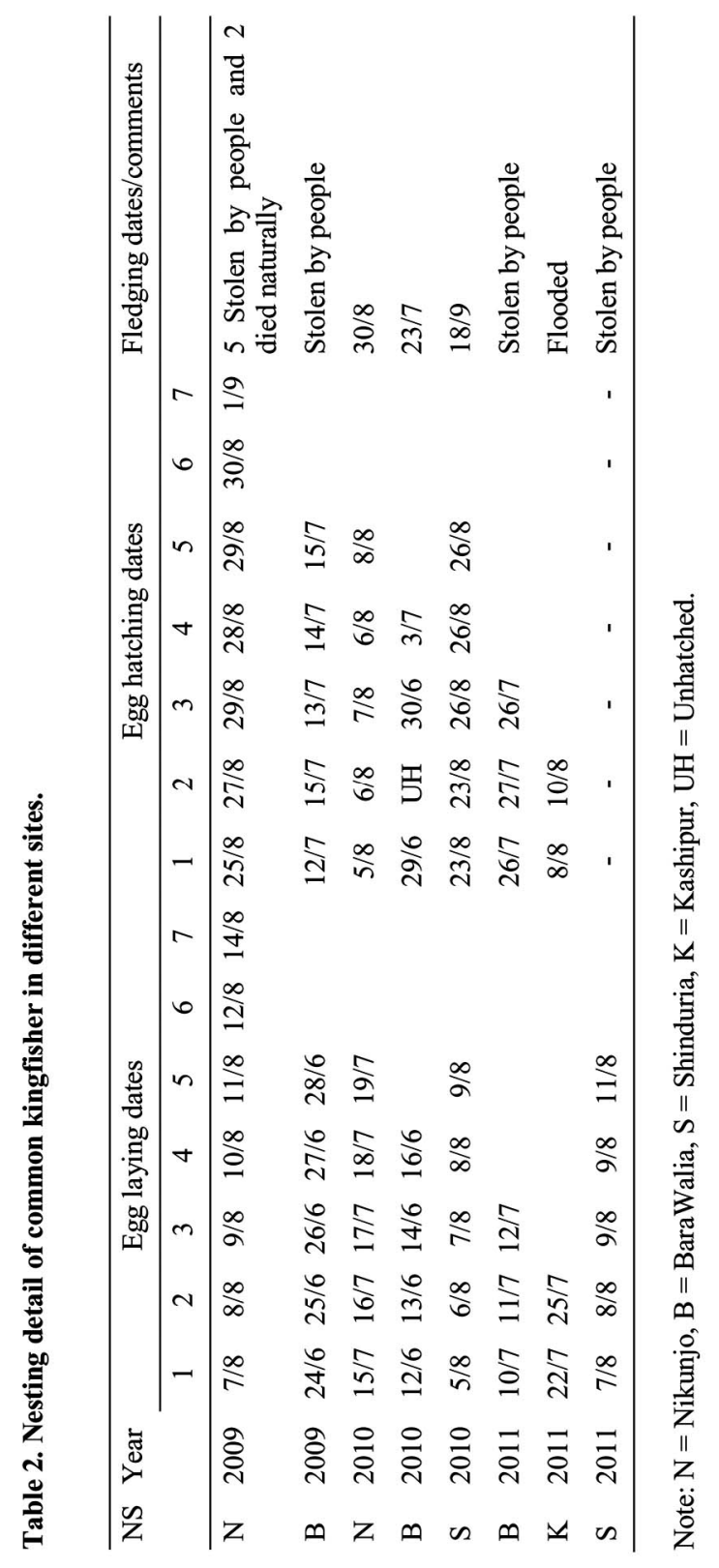


Breeding biology of common kingfisher

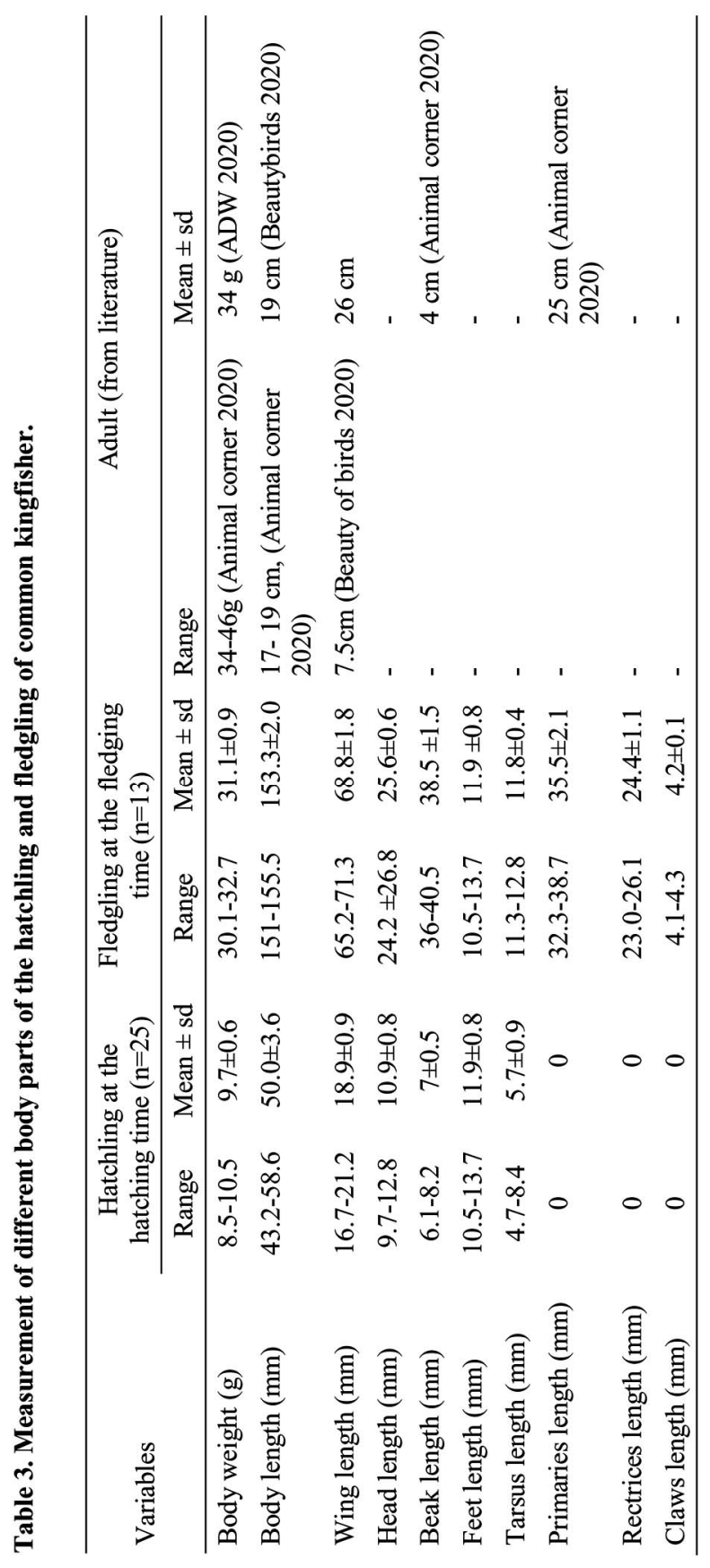


Fledging success: The fledging success was $43.3 \%(\mathrm{n}=30)$. The hatchlings were failed to fledge due to different reasons (Fig. 6), of which stolen by people was the leading cause $(76 \%$ ). Mean fledgling per nest was $2.0 \pm 2.3$ (nest no $=8$ ). One nest was built in July in Kashipur in 2011, which was flooded in August with two hatchlings due to heavy rainfall. Nestlings also die from flooding of the nest (ADW 2020). Also, bioaccumulation of pollution and toxins in fish affects the mortality rates of Kingfishers (ADW 2020).

The fledglings were almost similar to the adult in size (Table 3, but with duller and greener upperparts and paler underparts. It was also reported in Animal Corner (2020). Its bill was black, and initially, the legs have also remained black.

Breeding success: The breeding success was $36.1 \%$ in relation to eggs laid and $43.3 \%$ in relation to young fledged, whereas the mortality rate was $63.9 \%$ and $56.7 \%$, respectively. Kingfishers have relatively high reproductive rates, compensating for increased mortality in some areas (Fioratti 1992, Rayner et al. 1991).

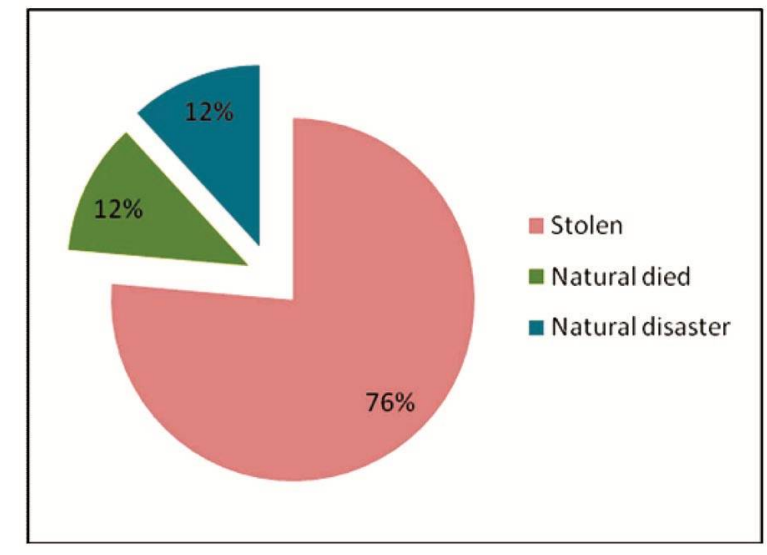

Fig. 6. Causes of loss of nestlings during the nesting period.

The common kingfishers build their nests near wetlands. As our country's wetlands are declining at an alarming rate, their nesting sites are under threat. Moreover, sudden fill-up of wetlands by the owners without concerning their nests decreases reproductive success. Regular cleaning activities of the owners at the bank of water bodies also destroy their nests. Besides, nests are also flooded by rising water levels caused by sudden heavy rainfall. In accordance with this, local boys steal the eggs and nestlings, and enhance the mortality rates. Additionally, cutting trees like, Sisoo (Dalbergia sissoo), Koroi (Albizia 
procera), Gagan siris (Albizia richardiana), Tunt (Morus indica), Shimul (Bombax ceiba), Jhau (Casuarina littorea), Jiga (Lannea coromandalica) around the water bodies is another cause which was used for preying, resting, bathing and diving. They preferred to use 3 to $10.2 \mathrm{~m}(7.4 \pm 2.3, \mathrm{n}=14)$ height trees or brunches. As they live on fishes and insects, fish farmers trap them and kill them in Nikunjo 1 . More than sixty percent of nests were destroyed due to anthropogenic reasons. If it were possible to check, the breeding success would increase. However, people should be aware to conserving the nest sites and habitat around the wetlands to conserve this species in nature.

\section{Acknowledgements}

The authors are grateful to the Ministry of Science, Information and Communication Technology (Bangabandhu fellowship) for funding the research. In addition, the authors would like to express their heartiest gratitude to the villagers who helped in different ways during data collection.

\section{References}

Ali, S. and S.D. Ripley. 1983. Handbook of the birds of India and Pakistan together with those of Bangladesh, Nepal, Bhutan and Sri Lanka. Vol.4.Oxford University Press, New York. pp. 265.

Ali, S. and S.D. Ripley. 1987. Compact handbook of the birds of India and Pakistan. Second edition. Oxford University Press, New York. pp. xlii +737 .

Altmann J. 1974. Observational study of behaviour: Sampling methods. Behaviour 49: 227- 267.

Anderton, J. and P. Rassmussen, 2005. Birds of South Asia. The Ripley Guide. Vols. 1 and 2. Barcelona: Smithsonian Institution and Lynx Edicions.

Animal corner 2020. Available at http://www.animalcorner.org.>animals>common-kingfisher, Accessed date 10-04-2020.

ADW. 2020. Available at http://animaldiversity.org.>accounts>alcedo_atthis, Accessed date 8-042020.

Beautybirds 2020. Available at http://www.beautyofbirds.com.>common-kingfishers, Accessed date 10-04-2020.

Campos, F., A. Fernandez, F. Gutierrez-Corchero, F. Martin-Santos and P. Santos. 2000. Diet of the Eurasian Kingfisher (Alcedo atthis) in northern Spain. Folia Zool. 49: 115-121.

Cramp, S., R. Douthwaite, K. Reyer and Westerturp. 1988. Ceryle rudis (Linnaeus). Pied Kingfisher. In: H. Fry, S. Keith, E. Urban, eds. The Birds of Africa. Vol III, San Diego: Academic Press. 299-302.

Finn, F. 1978. The Birds of Calcutta. $3^{\text {rd }}$ edition. Periodical Experts Book Agency, Delhi. pp. viii+166.

Fioratti, P. 1992. Kingfisher. Harper Collins Publishers. London.

Flegg, J. 1984. Discovering Birds. The Hamlyn Publishing Group Limited, London. pp. 176.

Grimmett, R., C. Inskipp and T. Inskipp. 1998. Birds of the Indian Subcontinent. Oxford University Press, New Delhi. pp. 1-888. 
Heneberg, P. 2004. Soil particle composition of Eurasian Kingfishers' (Alcedo atthis) nest sites. Acta Zool. Acad. Sci. Hunga. 50: 185-193.

Iribarren, I.B. and L.D. Nevado. 1982. Contrubution l'etude du régime alimentaire du MartinPecheur (Alcedo atthis L. 1758). Alauda 50: 81-91.

Jerdon, T.C. 1982. The Birds of India. Vol. 1. The Military orphan press, Calcatta. pp. xlv+535.

Kasahara, S. and K. Katoh. 2008. Food-niche differentiation in sympatric species of Kingfishers, the Common Kingfisher Alcedo atthis and the Greater Pied Kingfisher Ceryle lugubris. Orni. Sci. 7(2): 123-134.

Klomp, J.R. 1970. The determination of clutch size in birds - review. Ardea 58(1): 1-124.

Lessels, C.M. and J.R. Krebs. 1989. Age and breeding performance of European Bee-eater. Auk 106: $375-383$.

Li, P.J. and T.E. Martin. 1991. Nest-site selection and nesting success of cavity-nesting birds in high elevation forest drainages. Auk 108: 405-418.

Martin, T.E. and J.J. Roper. 1988 Nest predation and nest-site selection of a western population of the hermit thrush. Condor 90: 51-57.

Morgan, R. and D. Glue. 1977. Breeding, mortality and movements of Kingfishers. Bird Study 24:15-24.

Naher, H. and N.J. Sarker. 2015. Feeding techniques of Common Kingfisher (Alcedo atthis). Jagannath Univ. J. Sci. 4(II): 67-75.

Naher, H. and N.J. Sarker. 2016. Nest and nest characteristics of Common (Alcedo atthis) and White-throated Kingfisher (Halcyon smyrnensis). Bangladesh J. Zool. 44(1): 99-110.

Naher, H. and N.J. Sarker. 2018. Provisioned food to the nestlings of common kingfisher (Alcedo atthis) and white-throated kingfisher (Halcyon smyrnensis) by their parents. Jagannath Univ. J. Life and Earth Sci. 4(2): 176-186.

Ó Connor, R.J. 1984. The growth and development of birds. Wiley and Sons, New York.

Partridge, L. 1981. Habitatwahl. pp. 273-291. In: KREBS, J. R. and DAVIES, N. B. (eds): ÖkoEthologie. Scientific Publications. Oxford. London. 273-291.

Peris, S.J. and R. Rodriguez. 1996. Some factors related to distribution by breeding Kingfisher (Alcedo atthis L.). Ekol. Pol. 44: 31-38.

Peris, S.J. and R. Rodriguez. 1997. A survey of the Eurasian Kingfisher (Alcedo atthis) and its relationship with watercourses quality. Folia Zool. 46: 33-42.

Raven, P. 1986. The size of minnow prey in the diet of young Kingfishers, Alcedo atthis. Bird Study. 33: 6-11.

Rayner, J., U. Norberg and M. Brooke. 1991. Movement, A survey of modern birds. In: Brooke, M., Birkhead, T. eds. The Cambridge Encyclopedia of Ornithology. $1^{\text {st }}$ edition. The press syndicate of the University of Cambridge, New York. pp. 62.

Reynolds, S.J. and M.D.C. Hinge. 1996. Foods brought to the nest by breeding Kingfishers Alcedo atthis in the New Forest of southern England. Bird Study 43(1): 96-102.

Sayako, N., K.S.A. Tatsuhiko and K. Ryozo. 2002. Breeding status of Common Kingfishers Alcedo atthis in the Imperial Palace Ground and the Akasaka Imperial Grounds. J. Yamashina Inst. for Orni. 34(1): 112-125.

Singer, D. 1996. Collins Nature guide Garden Birds of Britain and Europe. Harper Collins Publishers, German. pp. 159.

Whistler, H. 1986. Handbook of Indian Birds. Cosmo Publications, New Delhi. pp. xxiv +438 . 